\title{
The Trinity: Prototype of Real Existence or Danger to Political Wellbeing? Tanner, Volf, and Yannaras in Conversation
}

\author{
Jonathan Cole
}

check for updates

Citation: Cole, Jonathan. 2021. The Trinity: Prototype of Real Existence or Danger to Political Wellbeing? Tanner, Volf, and Yannaras in Conversation. Religions 12: 998. https://doi.org/ $10.3390 /$ rel12110998

Academic Editors: Anastasia Mitrofanova and Sharyl Cross

Received: 28 September 2021 Accepted: 11 November 2021 Published: 14 November 2021

Publisher's Note: MDPI stays neutral with regard to jurisdictional claims in published maps and institutional affiliations.

Copyright: (c) 2021 by the author. Licensee MDPI, Basel, Switzerland. This article is an open access article distributed under the terms and conditions of the Creative Commons Attribution (CC BY) license (https:/ / creativecommons.org/licenses/by/ $4.0 /)$.
Centre for Public and Contextual Theology, Charles Sturt University, Canberra 2600, Australia; jcole@csu.edu.au

\begin{abstract}
Kathryn Tanner maintains that political theologies based on the Trinity are not only unsound, but potentially dangerous. Her primary concern is that the Trinity, by definition, cannot serve as a "model" for human socio-political organization. Miroslav Volf, while sharing Tanner's sense that Trinitarian political theologies are fraught, nevertheless, maintains that the Trinity can serve as a "vision" for human socio-political relations, albeit not as a "program". This article brings Tanner and Volf into conversation with Eastern Orthodox philosopher-theologian Christos Yannaras, whose Trinitarian political theology regards the Trinity as the "prototype" or "archetype" of a mode of existence in which humans can participate by transcending their natures, with the aim of realizing truth. This article argues that Yannaras offers a novel way of conceptualizing Trinitarian political theology which escapes Tanner and Volf's criticisms, on the one hand, and offers Social Trinitarianism a fresh and fertile perspective that could advance its discourse.
\end{abstract}

Keywords: Kathryn Tanner; Miroslav Volf; Christos Yannaras; Trinity; political theology; existence; Social Trinitarianism

\section{Introduction: The Danger of Trinitarian Political Theologies}

Kathryn Tanner, in her chapter on the Trinity in the Blackwell Companion to Political Theology, avows that "figuring out the socio-political lessons conveyed by the Trinity is a task fraught with complexities and perils" (Tanner 2004, p. 321). She is not alone in this concern. Miroslav Volf, echoing Tanner, has suggested that "the road from the doctrine of the Trinity to proposals about global or national social arrangements is long, torturous, and fraught with danger". ${ }^{1}$ Tanner identifies three primary impediments to the development of a viable political theology based on the doctrine of the Trinity. Firstly, the meanings of the terms used of the Trinity-Father, Son and Spirit-are not clear enough to inform human relations. Secondly, what is routinely said of the Trinity is not directly applicable to human beings. "Human society," Tanner notes, "could take on the very shape of the Trinity only if people were no longer human". Thirdly, on account of human sin and suffering, political proposals derived from the "peaceful and perfectly loving mutuality of the Trinity" seem "unrealistic, hopelessly naïve, and for that reason, perhaps even politically dangerous" (Tanner 2004, pp. 324-26). The source of Tanner's anxiety regarding the political potential of the Trinity stems from what she describes as "the ineradicable possibility of non-progressive uses" (Tanner 2004, p. 323). The historical record, in her view, attests that Trinitarian political theologies have far too infrequently been associated with egalitarian politics and a respect for diversity (Tanner 2004, p. 322). To understand Tanner's concern about "non-progressive uses" of the Trinity we must look to her own substantive work in political theology, The Politics of God: Christian Theologies and Social Justice. ${ }^{2}$ In it, Tanner expressly set out to show how Christian beliefs about God and the world may be disentangled from a history of use in support of a status quo of injustice and reconstituted as a resource for commitment to progressive social change. ${ }^{3}$

To that end, Tanner identified two Christian beliefs which in her view can be duly reconstituted in such a way that promotes progressive social change. These are God's 
transcendence and universal providential agency (Tanner 1992, p. 31). In brief, the utter transcendence of God demands the desacralization of all modes of human political organization, thus opening the door to their critique on the basis of transcendent notions of justice. Justice in turn is effected by God working providentially through human agency (Tanner 1992, pp. 32, 39). A fulsome exposition and analysis of Tanner's political theology is beyond the scope of the present article. Suffice to say, the task of political theology, as she conceives it, is to identify and reconstitute historical theological doctrines with the potential to promote progressive social change, and the Trinity is not such a doctrine.

Tanner's criticisms of the political potential of the Trinity reflect a common and dominant way to conceptualize the purported connection between the Trinity and human politics, which is to think in terms of a "model" or "program," i.e., the extent to which human political association or organization can and should reflect, mirror, or imitate the inner life of God. ${ }^{4}$ Volf similarly evinces concerns about the notion that the Trinity could serve as, or constitute, a socio-political "program" (Volf 1998, p. 406). However, both Tanner and Volf, although critical of the paradigm of "model" and "program," demonstrate that these concepts form the axis on which discourse about the political potential of the Trinity turns. In what follows, I bring the Trinitarian political theology of Eastern Orthodox philosopher-theologian Christos Yannaras into critical dialogue with Tanner and Volf. ${ }^{5}$ I will argue that Yannaras' Trinitarian political theology mitigates or avoids the risks identified by Tanner in relation to Trinitarian political theologies. I will further argue that Yannaras approaches the question of the political potential of the Trinity through a different paradigm to "model" and "program," one which views the Trinity as an archetypical or prototypical mode of being that humans can participate in by transcending their individualistic natures, and that this paradigm has the potential to broaden the horizon of current discourse on the political potential of the Trinity in fertile ways.

\section{God's Trinitarian Mode of Existence}

Yannaras maintains that God signifies a mode of existence, not a nature, essence, or entity (Yannaras 2002, p. 29; Yannaras 2016, p. 21). At its most succinct, God is to be understood as "a how, not a what or a something". ${ }^{6}$ According to Yannaras, God's mode of existence is "personal," which he defines as free and distinct, i.e., God is unique, unpredetermined and unconstrained by necessity. Personal is a relational category in Yannaras' thought, something he derives from the etymology of the Greek word for person,

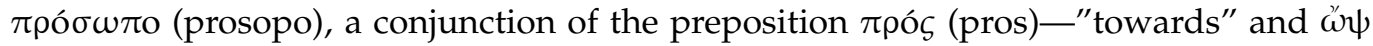
(ops) - "face". A person therefore stands in relation to someone or something and is defined by that relation (Yannaras 2016, p. 33). The Trinity apophatically describes the relational manifestation of the personal mode of existence denoted by "God". The distinct Person of the Father freely and lovingly begets the Son and causes the Holy Spirit to proceed, thus forming a communion of distinct persons in freedom and love. "Trinity" thus describes the divine mode of existence.

Unlike God, humans are characterized by a common created, and thus finite and corruptible, material nature. However, humans are called by God to transcend their common created natures and realize their unique, dissimilar, and unrepeatable personhood. The Trinitarian "prototype" or "archetype" of existence denotes the realizable potential of natural individuals to transcend biological necessity and attain personhood via entering into free and loving interpersonal communion with God, other human beings and the surrounding natural world (Yannaras 1998, 2019). 8

Interpersonal communion, however, cannot be compelled, for there is no compulsion in love and freedom, the defining marks of personhood. As such, humans are free to choose two alternative modes of existence: one a purely material existence in which natural individuals strive to secure their self-preservation and satisfy their selfish wants and needs, and another to form a loving interpersonal communion which is self-transcendent and self-offering (Yannaras 2016, pp. 43-44). Yannaras characterizes the latter mode of existences as ó $\vee \tau \omega \zeta \zeta \omega \eta^{\prime}$ (ontos zoi)—“real existence" or "genuine existence". ${ }^{9}$. The former 
he characterizes as existential failure (sin) insofar as it constitutes a failure to realize the "true existence" of interpersonal communion. The first humans, according to Yannaras, rejected the call to interpersonal communion with God and his creation in favor of selfish individualism in what Christian tradition has come to know as the fall (Yannaras 2016, p. 90). The Trinitarian prototype of existence thus denotes the existential potential of human beings to transcend the necessity of biological individualism and attain salvation in the form of free interpersonal participation in God's Trinitarian mode of existence.

\section{Politics as the Shared Struggle for Truth According to the Trinitarian Prototype of Real Existence}

Yannaras regards politics as the shared existential struggle to realize truth. ${ }^{10}$ This conception of politics is taken from the ancient Greek understanding of the polis. Yannaras maintains that the polis, which is to say "politics," in its original Greek sense of "things pertaining to the polis" ( $\tau \dot{\alpha} \pi \mathrm{o} \lambda \iota \tau \iota \kappa \alpha$ —ta politika), was originally conceived as a relational communion striving to live a shared life of truth. "Truth" in this context is construed in the Greek etymological sense of "unhidden". ${ }^{11}$ To understand Yannaras' conception of truth as unhidden, and its connection to politics, we must turn to his fundamental epistemology, which could aptly be described as "experiential-communitarian". Yannaras believes only shared experience provides reliable access to reality. Language, as our primary conceptual vehicle and mode of communication, is a conventional system of signifiers that point to real, objective signifieds that can only truly be known through experience, not the intellect alone. The truth of signifieds, which is to say their unveiling or revelation, can only be accomplished communally because it is only when the majority are able to testify to shared, convergent individual experiences of the same signified denoted by conventional linguistic signifiers that true existence progressively emerges and becomes manifest. This gives the polis an existential purpose or telos, with the result that politics is properly conceived as the collective human struggle to reveal the truth of real existence.

In the ancient Greek polis, it was the permanent, unchanging, harmonious, and, above all, impersonal rational order that the Greeks sought to reveal and mirror in their collective political life (Yannaras 1998, p. 71). Christianity, in Yannaras' view, did not alter this Greek conception of politics per se, i.e., the idea that the polis served an ontological-epistemological function. Rather it altered or, perhaps better, more fully revealed the content of the truth to which the common struggle of the polis aspired. The Christian ecclesial experience, recalling the function of Yannaras' experiential-communitarian epistemology, discovered that the impersonal common logos of the Greek universe was actually the logos of a totally other creative loving communion of Persons constituting the trinitarian first cause of the existent (Yannaras 1998, pp. 71-72). As Yannaras explains, "the First Cause of existence and existents is, according to ecclesial experience, the freedom of mutual love, a freedom that exists because it wills to exist, and that wills to exist because it loves (Yannaras 2019, p. 155). It is God's mode of being, not his nature, in which humans are able to participate by forming loving relationships of communion that transcend the natural biological instincts of the species for selfish individuality and self-protection. The significance of the ecclesia and the polis is that they form complementary communities of communion through which humans can realize their new existential mode of existence. Yannaras has something along the lines of the Byzantine paradigm of synallilia in mind here. Synallilia technically denotes two concepts which both belong to the same higher order concept, which in this context is to suggest that the church and the state form complementary parts of a larger or higher whole. Given Christianity is fundamentally about a mode of existence, according to Yannaras, it necessarily encompasses politics.

The locus of this new Trinitarian mode of existence is the eucharistic life of the ecclesial community established by the incarnation, the moment in history when God demonstrated in Jesus Christ the potential for created material human natures to enter into transcendent communion with the uncreated first cause of existence. "The eucharist," Yannaras maintains, "unifies the life of persons in the community of Christ's theanthropic 
nature, and thus restores the image of ... the fulness of trinitarian, personal communion, to man's being or mode of existence" ${ }^{12}$ Through the eucharist, human beings transform their individual biological need for nourishment into an ecclesial event of human fellowship in communion with God (Yannaras 1984, p. 188).

By locating politics within an existential context and according it a transcendent telos, Yannaras leaves practical questions of political organization open, matters to be settled by an exercise of human freedom and judgment. The Trinity, as far as Yannaras is concerned, does not suggest, nor does it demand, any specific "model" of political organization that the Christian community is supposed to emulate or implement in any deontological sense. The Trinity expresses God's mode of existence and the incarnation inaugurates a new reality of existential plenitude in which humans, provided they accept the divine call to self-transcendent relationship, can participate. All socio-political structures and relations, real and potential, are to be judged and discerned according to the extent to which they foster or inhibit this existential plenitude (Yannaras 1998, p. 126).

In Yannaras' view, the incarnation changed nothing about politics per se, given politics is, and always will be, the collective human existential struggle for truth. What accounts for variation in political organization and practices, both synchronic and diachronic, is that human communities prioritize their existential needs differently and possess differing conceptions of reality. As a consequence, civilizations, states, poleis and political communities are capable of drawing closer or falling further away from the truth of the cosmos. In that sense, it is not some ideal political organization or timeless, universal political order that the gospel reveals, but rather the true form of existence to which the common human political "struggle" can and should be oriented. ${ }^{13}$ Once the nature of "true existence" has been comprehended, human wisdom can pursue the task of discerning which organizational forms are conducive to or inhibitive of the realization of a mode of human existence in the mold of the Trinitarian prototype of existence. ${ }^{14}$ Yannaras thinks direct democracy, shared authority, productive use of property for the common good, meaningful work which fosters personal expression and a judicial system that prioritizes the justice of relationships rather than standardized behaviors can facilitate, sustain and preserve interpersonal communion. None of these political positions is justified by reference to the Trinity, however (Yannaras 1984, pp. 307-8; Yannaras 1998, pp. 35, 37, 95). Conversely, contractarianism, utilitarianism, materialism, consumerism, individualism and the priority of individual rights militate against the realization of interpersonal communion, in Yannaras' analysis. The latter, which comprise the prevailing political order in Western liberal democracies, including Yannaras' native Greece, reflect existential failure and have produced widespread alienation, the very antithesis of interpersonal communion.

\section{Is Yannaras' Trinitarian Political Theology Dangerous?}

By approaching the Trinity as a mode of existence rather than a replicable model of human political organization, Yannaras is ostensibly able to mitigate, if not avoid, Tanner's criticisms regarding the political implications of a Trinity-centric political theology. It is not the concepts that express the Trinity per se, i.e., Father, Son, and Spirit, that illuminate human political organization for Yannaras, but rather the existential mode of existence they signify, namely a relational communion predicated on personhood, freedom, and love. This mode of existence does not speak to God's essence and nor is there any suggestion that humans are to be incorporated into this essence or are able to mirror or even participate in it. It is noteworthy that the concept of theosis does not feature significantly in Yannaras' political theology, even though it is the central doctrine in other contemporary Orthodox political theologies. ${ }^{15}$ Yannaras' contention is that the created human nature can, through an act of self-transcendent response to the divine call to relationship, enter into communion with the uncreated in a way that has consequences for political life (again, in the Greek sense of the term). In Yannaras' Trinitarian political theology, specific principles of political organization are not derived from the "peaceful and perfectly loving mutuality of the Trinity" that is the source of Tanner's concerns relating to the dangers of a political theology 
based on the doctrine of the Trinity. Yannaras' construal of the Trinity as an archetypical mode of existence in which humans can potentially participate leaves the specific principles and policies of human political organization open to an exercise of human judgment, as we indicated above. Tanner may agree or disagree with one or more of Yannaras' political preferences, such as direct democracy or shared political authority, but none of these is claimed to derive from the Trinity per se, and therefore to have the imprimatur that ensues from forming a divine political model.

Moreover, far from leading to a dangerous political naivete, in Tanner's sense, Yannaras' Trinitarian political theology leads to a persistent and withering critique of the Western liberal status quo precisely because his conception of the Trinitarian prototype of existence leads him to identify it as existential failure, as existential alienation from the true telos and potential of human existence. "Political theory," Yannaras contends, "based on a trinitarian model ... is in every way critical because it compares the fullness of personal communion to our social reality" (Yannaras 1983b, p. 55). This gives political theology or, strictly speaking, the ecclesial community a "prophetic" function. Indeed, the more critical this prophecy is, in Yannaras' view, "the more directly it manifests the truth, transfiguring human failure to the measure of the revelation of the authenticity of human existence" (Yannaras 1983b, p. 56). The political import of the Trinity is not that it reveals a prescriptive sacred political order to be implemented, but rather "incarnate[s] the critical and radical irruption of truth in actual periods of historical life" (Yannaras 1983b, p. 56). Allowing for differences of language, conceptuality and theological presuppositions, Yannaras' critique does not appear to be broadly out of step with Tanner's own critique of Western civilization, culture, and, political malformation in spite of its Trinitarian emphasis, although she might be inclined to count this among the exceptions that prove the rule that Trinitarian political theologies do not generally lead to stances critical of the status quo. ${ }^{16}$

\section{Volf's Social Trinitarianism and Yannaras' Trinitarian Prototype of Real Existence}

We now turn our attention to Social Trinitarianism, which appears to be what Tanner mostly had in view in making her criticisms of Trinitarian political theologies discussed above. ${ }^{17}$ It also happens to be a theological movement that Yannaras has not engaged in his own work and which in turn has not engaged Yannaras, raising the question of how Yannaras' distinct Trinitarian political theology relates to it. Given "the differences among social trinitarians are vast," we limit our focus here to an engagement with the Social Trinitarianism of the author of that observation, Miroslav Volf (Volf 2021, p. 408). ${ }^{18}$ In "“The Trinity Is Our Social Program": The Doctrine of the Trinity and the Shape of Social Engagement," Volf mounts a critique of Russian Orthodox intellectual Nicholas Fedorov's famous dictum: "The dogma of the Trinity is our social program". ${ }^{19}$ His consternation stems from the underlying theological presupposition that Christ's resurrection brings humanity "into a new ontological state marked by participation in the divine life," a concern which at first glance might be applicable also to Yannaras. ${ }^{20}$ Volf's social Trinitarian counterproposal to Fedorov is further apposite to the present discussion insofar as it exhibits some conceptual convergence with Yannaras', in that it privileges the concepts "person," "relation" and "perichoresis". 21

Volf sees two pitfalls ("unacceptable options") confronting those who would seek to relate, as they ought to in his opinion, the doctrine of the Trinity to human social reality: one that seeks a human imitation of the inimitable Triune God and one that respects creaturely difference from God, but fails to pursue the human calling to be like God (Volf 1998, p. 405). The Trinity is essential, not optional, to Christian reflection on the forms of human social life (Volf 2021, p. 419). To that end, Volf pursues what could be described as a via media Trinitarian political theology, one based on the idea of copying God in some respects, but not others (Volf 1998, p. 405). In a more recent articulation, Volf has stated that he "espouses a strictly perichoretic account of the identity and relation between divine persons, human analogues to which, though existent and important, are distant" (Volf 2021, p. 408). Thus, unlike Tanner who regards the very project of vesting Christian political theology 
in the Trinity as ill-advised and even dangerous, Volf only regards some attempts at a Trinitarian political theology as misconceived and perilous, while regarding the project as fundamentally sound and vital.

Volf identifies two limiting principles that guide his Trinitarian via media. The first is to recognize that the ontic and noetic gulf between humans and God means that Trinitarian concepts such as "person," "relation" and "perichoresis" can only be applied analogously to human community. The second is that the constant of human sin and human embeddedness in a dynamic history mean that humans are only able to correspond to the Triune God in historically conditioned ways. ${ }^{22}$

Volf regards Fedorov's dictum as "specious" and "chimerical," but grounded in a fundamentally sound insight, namely, that the doctrine of the Trinity does indeed entail a "social program," or as Volf would prefer to conceptualize it, a "social vision" " (Volf 1998, pp. 403, 406). A Trinitarian "program" is theologically untenable, as far as Volf is concerned, because it violates the first of his two limiting principles-the Trinity simply cannot constitute the goal, plan, or system that is implied by the word "program" (Volf 1998, p. 43). By "vision," Volf means "the contours of the ultimate normative end toward which all social programs should strive" (Volf 1998, p. 43).

Two problems attend Volf's Trinitarian "social vision". The first is that the vision itself turns out to be less obviously Trinitarian than Volf seems to think or, if it is Trinitarian, it is so in a rather complex and obscure way. This is because the vision, after a genuinely insightful tour of Trinitarian theology, ends up where much Protestant political theology does, in Christology. In Volf's own words, his "proposal" rests on the question of the "social import of the 'empty tomb' and the translucent body of Christ ascending into heaven" (Volf 1998, p. 417). "The Crucified One," he avers, is the new creation-the perfect enactment of the eternal love of the Triune God in the godless world ... the Crucified One is the new creation as it enters into the present creation become old through the practice of injustice, deception, and violence in order to transform godless humanity into humanity made in the image of the Triune God. ${ }^{23}$

A second, and related problem is that it is far from clear what the "social vision" in question, irrespective of, or perhaps on account of, its Trinitarian opacity, means for humans in practice, i.e., what is to be implemented. Volf eschews attempts to employ the Trinity for projects that seek to re-arrange "socio-economic structures" in favor of a focus on "social agents and their relations," although he observes that this approach is in no way less "political" than the question of social structures (Volf 1998, p. 406). Be that as it may, Volf's preference for vision over program, whatever its relative merits, shifts the focus away from concrete political realities, questions, disputes, and actions towards a kind of Christian political rhetoric that, while doctrinally sound and enriching, provides little in the way of guidance to Christian political action. It was conservative philosopher Roger Scruton who made the wise observation that "the reality of politics is action," followed by the equally wise observation that "action derives, however covertly, from thought ... " (Scruton 2001, p. 1). The criticism is not that Volf's social trinitarian vision is incapable of shaping political action; if Scruton is correct, then this is a given, even if the causal relationship between thought and action is obscure to actor and observer alike. It is that Volf does not outline how his social trinitarian vision can, or should, be translated into political action beyond the domain of rhetoric. Yannaras' political vision too, it must be said, is open to a similar charge, although he does take more steps in the direction of implementation than Volf.

Volf rhetorically asks, "What, then, does the Trinitarian self-donation translated into the world and therefore enacted in the cross by the power of the Spirit mean for the life of human communities?" To this he provides a very Christological answer: the divine welcome in Christ, which the New Testament consistently portrays as "the model for Christians to emulate," translates into a willingness to "give ourselves to others and welcome them" (Volf 1998, pp. 415-16). Volf maintains that "to propose a social knowledge based on the doctrine of the Trinity" is not to "project" or "represent" the Trinitarian God, but to "re-narrate the history of the cross ... understood ... as the Triune God's engagement with 
the world in order to transform the unjust, deceitful, and violent kingdoms of this world into the just, truthful, and peaceful "kingdom of our Lord and of his Messiah" (Revelation 11:16)" (Volf 1998, p. 415). Volf's Trinitarian "social vision" thus ends in a form of imitatio Christi that is Trinitarian in a rather indirect way, by virtue of the fact that Christ expresses in some fashion the Triune God, and hence imitation of Christ in some way can be said to reflect the Trinity. Tanner observes that the Trinity often "fails to do any work" in strategies that aspire to human relations that imitate Trinitarian relations (Tanner 2004, p. 327). "We do not need the Trinity," she notes "to tell us that human beings condition one another by way of their relationships (Tanner 2004, p. 327). ${ }^{24}$ Indeed, Volf has conceded that a Christian might reasonably arrive at similar conclusions "about the nature of the self, social relations, and the good without reference to the developed doctrine of the trinity ... " (Volf 2021, p. 419). However, he still maintains that something is lacking if the Trinity is not part of the equation because it constitutes "the ultimate source of value ... not just of beliefs about what is valuable but also of our ability to embrace, hold onto, and embody these values in our lives" (Volf 2021, p. 420). Disentangling, reconciling and/or harmonizing the supposed political implications and potential of Christology and the doctrine of the Trinity remains a problem in political theology.

One clear element in Volf's social trinitarian vision is its directionality. In contrast to Fedorov's upwards motion, in which humanity is brought up into the life of the Triune God, Volf emphasizes a downward movement, whereby humanity's "social vision and social practices image the Triune God's coming down in self-emptying passion in order to take human beings into the perfect cycle of exchanges in which they give themselves to each other and receive themselves back ever anew in love" (Tanner 2021, p. 419). Tanner and Yannaras provide their own interesting contrasts with Volf and Fedorov on the question of directionality. Tanner shares Volf's concern to locate Christ at the epicenter of the relationship between the Triune God and humanity. However, unlike Volf, she envisages an upwards movement, albeit not through a paradigm of theosis like Fedorov. She contends that humans are drawn up into the life of the Trinity by imitating, being united with, perfected in, and co-inhering in Christ: "The assumption of humanity by the Son produces a co-inherence of divinity and humanity that better imitates the co-inherence enjoyed by members of the Trinity than does God's containing and pervading creation generally" (Tanner 2001, pp. 9, 48). ${ }^{25}$ Contra Volf, it is Jesus' expression of the Trinitarian God in his incarnate life that constitutes a suitable human "model" for imitation, according to Tanner (Tanner 2001, p. 52).

Yannaras takes a different approach altogether, and it is this that makes him a valuable contributor to Christian discourse on the relationship between the doctrine of the Trinity and politics. In Yannaras' political theology, God comes down into humanity in the form of the incarnation to inaugurate a new existential possibility for humanity. This new existential reality is not directional, but rather mediatory, in that it brings the created and uncreated into relationship in an eternal mode that is embodied in a finite material world. God came down to humanity in order to inaugurate this new existential potential. However, humans must choose to transcend their created human nature and respond to the divine call to relationship in order to make this new existential communion a reality. This is where politics comes into the equation. Politics is not modelled on the Trinitarian communion per se, nor does it implement some program based on or drawn from the Trinity. Rather it is a perpetual struggle to live a communal life that reflects God's Trinitarian mode of existence. This Trinitarian mode of existence forms a "prototype" or "archetype" of human political association. Some might regard these concepts as not sufficiently dissimilar to "model" to count as a genuinely new paradigm for thinking about the political potential of the Trinity. However, the idea here is one of human participation in, rather than imitation of, a divine prototype or archetype of existence, with the linguistic and conceptual implication being that the human political experience reflects, perhaps even resembles, but certainly does not replicate, the original. Communion between the created human nature-transcended, but not nullified-and the uncreated creator removes any possibility of full ontological union 
or exact replication. The objective of human politics is true existence, a type of existential plenitude that can only be attained in community, and then only through collective effort and struggle. Note that, unlike Tanner, this new existential possibility for humans is not predicated on imitating or becoming united with Christ per se.

\section{Conclusions}

As discussed above, Yannaras' approach ostensibly mitigates Tanner's concerns about Trinitarian political theologies. It also appears to evade Volf's just concern that "the image of the world as it ought to be can ... not simply be 'derived' from the trinity and 'applied' to the world as it is" (Volf 2021, p. 419). It further offers a different way to conceptualize the relationship between the Trinity and human socio-political existence, which is to think in terms of existential modes and divine "prototypes" and "archetypes," rather than models and programs. In that respect, Yannaras' can be thought of as a modal (tropos) Trinitarian political theology. The extent to which Yannaras' approach satisfactorily resolves all the problematics that attend discourse on the political potential of the Trinity and to which those who are inclined towards political theologies grounded in the Trinity might find it compelling are moot. Karen Kilby, yet another skeptic of the Trinitarian political theology project, may ultimately be right in suggesting that the best Christian political theology can aspire to vis à vis the Trinity is a kind of intellectual asceticism that resists the temptation to artificially make it more politically relevant than it is. ${ }^{26}$ However, given Christian theology continues to affirm, as it has for centuries, belief in a Triune God, it is only natural, if not unavoidable, that theologians will inquire after the political ramificaitons of this affirmation. In that regard, Yannaras' Trinitarian political theology offers this necessary discourse on the political potential of the Trinity, one which predominantly reflects the theological presuppositions, political contexts, and conceptuality of Western Christian theology, a means of broadening both its conceptual and ecumenical horizons in fecund ways.

Funding: This research received no external funding.

Institutional Review Board Statement: Not applicable.

Conflicts of Interest: The author declares no conflict of interest.

\section{Notes}

(Volf 1998, p. 406). More recently, Kilby has voiced similar concerns (Kilby 2020). Bauerschmidt notes that the idea that there is a connection between an understanding of political life and the Trinity is "rare, if not entirely unknown, prior to the twentieth century" (Bauerschmidt 2011, p. 531). Carl Schmitt introduced (reintroduced, according to some) the concept of political theology in 1922 with the publication of Politische Theologie: Vier Kapitel zur Lehre von der Souveranitat, although the term first found its way into English some time later via Ernst Hartwig Kantorowicz (Kantorowicz 1952, 1957), who adopted the term from Schmitt-Schmitt's Political Theology was not translated into English until 1985 (See (Schmitt 2005)). The Trinity is not mentioned in Schmitt's Political Theology, but it did assume a place of central importance in the work of his most prominent early critic, one time friend, theologian, and church historian Erik Peterson, who famously argued that God's Triune nature made the very notion of a political theology (here conceived in monarchic terms) impossible, notwithstanding the long Jewish and Christian tradition of attempts at precisely that (Peterson 1931, 1933, 1935). For an excellent overview of the Schmitt-Peterson debate, see (Geréby 2008). Schmitt responded directly to Peterson's arguments in Politische Theologie II, published in 1970 (not translated into English until (Schmitt 2008)), in which he indicted Peterson's Trinitarian rejection of political theology with the charge of being "apolitical". See (Passos 2018) for a good account of this final chapter in the Schmitt-Peterson debate. Schmitt's thought, including his reintroduciton of the concept of political theology, has spawned a growing literature ever since George Schwab rehabilitated his reputation and introduced him to English-language scholarship in (Schwab 1970), and subsequent translations, including Political Theology. For recent work on Schmitt, see (Vatter 2021; Herrero 2015). Peterson's work has received less attention than Schmitt's in English and only some of his writings have been translated, and then only relatively recently (Peterson 2011). Peterson's Trinitarian objection to the notion of a political theology has been sadly neglected in contemporary confessional political theology, although Moltmann's 1971 article "Political Theology" makes reference to it (I make a distinction here between what I call "secular" and "confessional" political theology, with the former denoting a type of historical analysis pioneered by Schmitt, and today primarily conducted by non-theologians, and the latter being a type of normative theological thinking conducted by theologians for and on behalf of the church-others have made a similar distinction, albeit without the precise langauge used here, e.g., (Cavanaugh and Scott 2019, p. 3; Bretherton 2019, p. 17; Laustsen 2013, p. 449). The Trinitarian 
political theology discourse discussed in this article, which belongs to the confessional side of the divide, has made little use of Schmitt and Peterson, and would benefit in particular from a serious consdieration of and engagement with Peterson's argument that the doctrine of the Trinity precludes political theology per se (along with Schmitt's response). It is worth noting, finally, that Schmitt's Christianity (or lack thereof), along with the role of theology in his thought, has become a subject of interest and dispute. For two recent perspectives, see (Roberts 2015; Geréby 2021).

2 (Tanner 1992, p. vii). Tanner expresses concern that the biblical account of the economic Trinity is "subordinationalist" and "ripe for justification of hierarchy" (Tanner 2004, p. 322).

3 (Tanner 1992, p. vii). This approach to political theology stands in the tradition begun by Metz and Moltmann, who both regarded political theology as a primarily critical and liberative task. See (Metz 1968; Moltmann 1971).

$4 \quad$ Volf provides an indicative example: "the question is not whether the Trinity should serve as a model for human community; the question is rather in which respects and to what extent it should do so (Volf 1998, p. 405). See also (van den Brink 2014, p. 332).

5 Yannaras' primary work was largely innacessible in English until relatively recently, and it is only now that the secondary literature has begun to emerge in a serious way. For significant recent works, see (Petrà 2019; Mitralexis 2018; Andreopoulos and Harper 2018). (Mitralexis 2019) provides a good overview of the development of Yannaras' political theology. Yannaras has provided an autobiographical account of his intellectual development in (Yannaras 2005, untranslated). Yannaras is something of a controversial figure in Greece. He is closely identified with the famous "generation of the 60s" theological movement that ushered in a "return to the Fathers" after a long period of Western inluence in Greek theology. For a detailed account of developments in Greek theology from the 1960s to the present, and Yannaras' place in it, see (Kalaitzidis 2014). Notwithstanding this association, he has had a turbulent relationship with the theological establishment of Greece, spending the bulk of his career (after being shut out of theology) as a professor of philosophy at Panteion University of Social and Political Sciences, where, amongst other subjects, he taught politics. Yannaras' long and regular political commentary in the Greek media (including a weekly column in newspaper Kathimerini), often characterized by unflinching and sometimes caustic criticism of virtually every political, cultural, and religious institution in Greece, has undoubtedly contributed to his controversial profile. With controversy inevitably comes misunderstanding and polarized reception. As Mitralexis wryly notes, in Greece "Yannaras has been considered as a leftist or a liberal by right-wingers, as a nationalist right-winger by lef-wingers, as an extremist by centrists and as way too soft by extremists (Mitralexis 2019, p. 313). Yannaras has been controversial outside of Greece for different reasons, namely, for being "anti-Western" and for his alleged creation of a constructed and false view of the West, although recent scholarship has questioned this reading of Yannaras. See, for example, (Gallaher 2018).

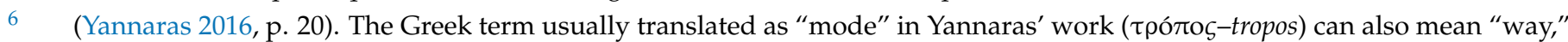
"means" or "manner".

7 (Yannaras 2016, p. 29). "Being cannot be reduced to an Essence, which would constitute ontological necessity, rather it stems from a Person and the freedom of his love, which instantiates Being in the form of a personal-trinitarian communion".

8 The term "Trinitarian prototype" occurs in (Yannaras 1998, pp. 114, 119, 123, 160). It appears in several different formulas: "the trinitarian prototype of real existence," "the trinitarian prototype of real existence and life," "mimesis of the trinitarian prototype," and "the divine trinitarian prototype of real existence". The term "Trinitarian archetype" occurs in (Yannaras 2019, p. 153).

9 (Yannaras 2016, p. 32). "Human beings are created for the purposes of becoming communicants in a personal mode of existence, which is to say the life of God-to become participants in the freedom of love, which constitutes "genuine existence""

10 For recent work on Yannaras' politcal thought and/or political theology, see (Skliris 2018, 2019; Cole 2018, 2019; Mitralexis 2019; Gounopoulos 2018).

11 (Yannaras 2019, pp. 127-28). The Greek word for truth is alitheia, formed from $a$ - "un" and lithi "hidden".

12 (Yannaras 2002, p. 82). Emphasis original.

13 Yannaras often describes politics as an $\alpha \theta \lambda \eta \mu \alpha$ (athlima), which means "sport" in Modern Greek, but here has the sense of "struggle" or "contest" for truth, the idea being that truth can only be attained through great effort and striving, and in the face of obstacles, namely alienation. See (Yannaras 2019).

14 Yannaras's first substantive intervention on political theology, one of the earliest by an Orthodox theologian, came in the form of a 1983 article titled "A Note on Political Theology" (a collection of his newspaper articles was published earlier under the title Chapters in Political Theology (Yannaras 1976). In it, he criticized political theology, in this context depicted as a "Western" enterprise, for its activist tendencies towards mobilizing "theologians and clergy in radical sociopolitical movements," p. 53. Yannaras returned to this theme in The Inhumanity of Rights, where he construed political theology, "so-called," as a CatholicProtestant project to develop a "theology of revolution" designed to allow Christians living under oppressive totalitarian regimes (particularly in the Third World) to participate in revolutionary and liberation movements (Yannaras 1998). Although not named, Yannaras certainly had the liberation theology of Latin America in mind in making these observations about political theology. It is less clear if Metz, whom he does not name, shaped this view at all. Interestingly, Yannaras himself was a prominent figure in a Christian-Marxist dialouge in Greece following the end of the military junta in 1974 (Skliris 2019, p. 339).

15 This is not to suggest that it is absent or unimportant in Yannaras' theology per se. For an example of an Orthodox political theology grounded in the notion of theosis, see (Papanikolaou 2012). 
16 It is worth noting Kalaitzidis' critique of Yannaras' political theology at this juncture, which is that it fails to generate any "social activism," nor "struggle for the protection of human dignity, and to solidarity with the victims of history, but on the contrary, it often encourages ... a flight from history and an undermining of social activity and collective struggle" (Kalaitzidis 2012, p. 40).

17 (Tanner 2004, p. 326). “Direct translation of the Trinity into a social program is problematic ... " While Karl Barth's Epistle to the Romans has been credited with sparking the "renaissance" in Trinitarian thelogy (Grenz, p. 3), it was Karl Rahner'sobservation that "Christians are, in their practical life, almost mere "monotheists'" that gave impetus specifically to the attempts of social Trinitarians to find relevance in the doctrine of the Trinity for human social and political life (Rahner 1970, p. 10).

18 Yannaras has shown little interest in or awareness of the thought of contemporary American or America-based Protestant theologians such as Tanner and Volf. This is partly due to his overriding interest in the Western European intellectual tradition, mainly German and French, and its impact on Greece (Yannaras lived and studied in both Germany and France and has been profoundly influenced by European philosphers such as Martin Heidegger and Jean-Paul Satre). Indeed, Yannaras' primary frame of reference for the West is his own Greece, a Western country in his view (and that of the world today), albeit one trapped culturally and spiritually between its Eastern heritage and Western institutions, mindset and contemporary mores.

19 (Volf 1998, p. 403). Volf, in this article, works with the concept of the "social" rather than the "political" per se. However, he defines "social" in such a way that it incorporates both politics and economics, thus bringing it into the orbit of the expansive definition of "political" with which Yannaras works.

20 Federov is mentioned in passing in Yannaras (1983b, p. 55) albeit not in the relation to the Trinity.

21 (Volf 1998, p. 403). Although not discussed above, perichoresis is an important concept in Yannaras' Trinitarian theology, although he tends to favor the Greek term aplliloperichoresi (Modern Greek transliteration)_"mutual interpenetration".

22 (Volf 1998, pp. 405-6). "By describing God in whose image humans are created and redeemed, the doctrine of the Trinity names the reality which human communities ought to image. By describing human beings as distinct from God, the doctrines of creation and of sin inform the way in which human communities can image the Triune God, now in history and then in eternity".

23 (Volf 1998, p. 418). Emphasis original.

24 One suspects that Tanner might be inclined to put the same question to Yannaras, and it would be a valid question. However, this question is not raised purely by Volf and Yannaras' attempts to ground political norms in the Trinity. The extent to which Trinitarian political theologies writ large say anything truly unique about human relationality and political association, beyond the unique idiom of Christian theology in which their claims are articulated, is an open question. It is also a question that is beyond the scope of the present article, because it could just as easily be asked of Christian political theology per se, given the intrinsic challenge of saying something cogent about the empirical reality of politics, not to mention any normative political propsosal, that could not be said in non-theological langauge and justified on philosophical, rather than theological, grounds. Indeed, the question could be turned around on Tanner. To what extent does her progressive political theology articulate anything that is not routinely articulated by secular progressives? Indeed, is her political theology even possible merely on the basis of Christian theological language and concepts, or is it actually shaped in some way by secular political ideas? That said, I do note that, even if, in the final analysis, it is true that all/most/much Christian political theology ends up saying little that is not, or could not, be said by secular thinkers, the point is that the theological idiom is essential for those whose entire worldview and ethical norms are shaped by theological language and ideas. It is precisely the theological idiom itself that makes certain political ideas, even those which converge with secular political ideas, meaningful and compelling to Christians. Admittedly, this view risks reducing Christian political theology to mere linguistics, an idiom lacking substantive distinction from non-theological political langauge. Even so, it is an incredibly important idiom given it is a living language spoken by hundreds of millions of humans who are of political consequence in places such as America, Africa, Latin America and parts of Asia. I am indebted to an anonymous reviewer for bringing this question to my attention.

25 Note the parallel here with Volf insofar as Tanner's conception of human participation in the Trinity is thoroughly Christological. This Christological reading of the Trinity is also on display in (Tanner 2010).

26 See (Kilby 2000). The articulation here is influenced by (Tanner 2021, p. 380). Kilby has elsewhere "sketch[ed] the contours" of a an approach to Trinitarianism that is "apophatic," which is to say, that emphasizes the transcendant otherness, and hence unknowability, of God, in contrast to the overrendered Trinitariasm of the late 20th century (Kilby 2010, pp. 66-68). Kilby has also intriguingly suggested that recrudescent interest in Trinitarianism might be a reaction against "thin rationalism" and "limp liberalism" (Kilby 2010, p. 66).

\section{References}

Andreopoulos, Andreas, and Demetrios Harper, eds. 2018. Christos Yannaras: Philosophy, Theology, Culture. London: Routledge. Bauerschmidt, Frederick Christian. 2011. The Trinity and Politics. In The Oxford Handbook of the Trinity. Edited by Gilles Emery and Matthew Levering. Oxford: Oxford University Press, pp. 531-46.

Bretherton, Luke. 2019. Christ and the Common Life: Political Theology and the Case for Democracy. Grand Rapids: Eerdmans.

Cavanaugh, William T., and Peter Manley Scott. 2019. Introduction. In Wiley Blackwell Companion to Political Theology, 2nd ed. Edited by William T. Cavanaugh and Peter Manley Scott. Hoboken: John Wiley \& Sons, pp. 1-11. 
Cole, Jonathan. 2018. The Problematic of Greek Identity and Christos Yannaras' Quest for a Politics of Authentic Existence. In Polis, Ontology, Ecclesial Event: Engaging with Christos Yannaras' Thought. Edited by Sotiris Mitralexis. Cambridge: James Clarke \& Co, pp. $47-63$.

Cole, Jonathan. 2019. Personhood, Relational Ontology, and the Trinitarian Politics of Eastern Orthodox Thinker Christos Yannaras. Political Theology 20: 297-310. [CrossRef]

Gallaher, Brandon. 2018. Orthodoxy and the West: The Problem of Orthodox Self-Criticism. In Polis, Ontology, Ecclesial Event: Engaging with Christos Yannaras' Thought. Edited by Sotiris Mitralexis. Cambridge: James Clarke \& Co, pp. 206-25.

Geréby, György. 2008. Political Theology versus Theological Politics: Erik Peterson and Carl Schmitt. New German Critique 35: 7-33. [CrossRef]

Geréby, György. 2021. The Theology of Carl Schmitt. Politeja 72: 21-49. [CrossRef]

Gounopoulos, Angelos. 2018. The Freedom of Relationship as the Ontological Foundation in Christos Yannaras' Political Theology. In Polis, Ontology, Ecclesial Event: Engaging with Christos Yannaras' Thought. Edited by Sotiris Mitralexis. Cambridge: James Clarke \& Co, pp. 64-79.

Grenz, Stanley J. Rediscovering the Triune God: The Trinity in Contemporary Theology. Minneapolis: Fortress Press.

Herrero, Montserrat. 2015. The Political Discourse of Carl Schmitt: A Mystic Order. London: Rowman \& Littlefield.

Kalaitzidis, Pantelis. 2012. Orthodoxy E Political Theology. Geneva: WCC Publications.

Kalaitzidis, Pantelis. 2014. New Trends in Greek Orthodox Theology: Challenges in the Movement Towards a Genuine Renewal and Christian Unity. Scottish Journal of Theology 67: 127-64. [CrossRef]

Kantorowicz, Ernst Hartwig. 1952. Deus Per Naturam, Deus Per Gratiam: A Note on Mediaeval Political Theology. The Harvard Theological Review 45: 253-77. [CrossRef]

Kantorowicz, Ernst Hartwig. 1957. The King's Two Bodies: A Study in Mediaeval Political Theology. Princeton: Princeton University Press.

Kilby, Karen. 2000. Perichoresis and Projection: Problems with Social Doctrines of the Trinity. New Blackfriars 81: 432-45. [CrossRef]

Kilby, Karen. 2010. Is an Apophatic Trinitarianism Possible? International Journal of Systematic Theology 12: 65-77. [CrossRef]

Kilby, Karen. 2020. God, Sin, and the Limits of Theology. London: T\&T Clark.

Laustsen, Carsten Bagge. 2013. Studying Politics and Religion: How to Distinguish Religious Politics, Civil Religion, Political Religion, and Political Theology. Journal of Religion in Europe 6: 428-63. [CrossRef]

Metz, John B. 1968. Religion and Society in the Light of a Political Theology. The Harvard Theological Review 61: 507-23. [CrossRef]

Mitralexis, Sotiris, ed. 2018. Polis, Ontology, Ecclesial Event: Engaging with Christos Yannaras' Thought. Cambridge: James Clarke \& Co.

Mitralexis, Sotiris. 2019. The Eucharistic Community is Our Social Program: On the Early Development of Christos Yannaras' Political Theology. Political Theology 20: 311-30. [CrossRef]

Moltmann, Jürgen. 1971. Political Theology. Theology Today 28: 6-23. [CrossRef]

Papanikolaou, Aristotle. 2012. The Mystical as Political: Democracy and Non-Radical Orthodoxy. Notre Dame: University of Notre Dame Press.

Passos, Eduardo Schmidt. 2018. The Blood of the Martyrs: Erik Peterson's Theology of Martyrdom and Carl Schmitt's Political Theology of Sovereignty. The Review of Politics 80: 487-510. [CrossRef]

Peterson, Erik. 1931. Göttliche Monarchie. Theologische Quartalschrift 112: 537-64.

Peterson, Erik. 1933. Kaiser Augustus im Urteil des antiken Christentums: Ein Beitrag zur Geschichte der politischen Theologie. Hochland 30: 288-89.

Peterson, Erik. 1935. Der Monotheismus als politisches Problem: Ein Beitrag zur Geschichte der politischen Theologie im Imperium Romanum. Leipzig: Hegner.

Peterson, Erik. 2011. Theological Tractates. Translated and Edited by Michael J. Hollerich. Stanford: Stanford University Press.

Petrà, Basilio. 2019. Christos Yannaras: The Apophatic Horizon of Ontology. Translated by Norman Russell. Cambridge: James Clarke \& Co.

Rahner, Karl. 1970. The Trinity. Translated by Joseph Doncel. London: Burns \& Oates.

Roberts, Aaron B. 2015. Carl Schmitt-Political Theologian? The Review of Politics 77: 449-74. [CrossRef]

Schmitt, Carl. 2005. Political Theology. Translated and with an introduction by George Schwab, with a new foreword by Tracy B. Strong. Chicago: The University of Chicago Press.

Schmitt, Carl. 2008. Political Theology II: The Myth of the Closure of any Political Theology. Translated and introduced by Michael Hoelzl and Graham Ward. Cambridge: Polity.

Schwab, George. 1970. The Challenge of the Exception: An Introduction to the Political Ideas of Carl Schmitt between 1921 and 1936. Berlin: Duncker \& Humblot.

Scruton, Roger. 2001. The Meaning of Conservatism, 3rd ed. Basingstoke: Palgrave Macmillan.

Skliris, Dionysius. 2018. Christos Yannaras' Political Ontology: An Introductory Sketch. In Polis, Ontology, Ecclesial Event: Engaging with Christos Yannaras' Thought. Edited by Sotiris Mitralexis. Cambridge: James Clarke \& Co, pp. 19-46.

Skliris, Dionysius. 2019. Aristotelian Marxism, Critical Metaphysics: The Political Theology of Christos Yannaras. Political Theology 20: 331-48. [CrossRef]

Tanner, Kathryn. 1992. The Politics of God: Christian Theologies and Social Justice. Minneapolis: Fortress.

Tanner, Kathryn. 2001. Jesus, Humanity, and the Trinity: A Brief Systematic Theology. Minneapolis: Fortress. 
Tanner, Kathryn. 2004. Trinity. In The Blackwell Companion to Political Theology. Edited by Peter Scott and William T. Cavanaugh. Oxford: Blackwell, pp. 319-32.

Tanner, Kathryn. 2010. Christ the Key. Cambridge: Cambridge University Press.

Tanner, Kathryn. 2021. The Limits of Political Theology. Political Theology 22: 379-84. [CrossRef]

van den Brink, Gijsbet. 2014. Social Trinitarianism: A Discussion of Some Recent Theological Criticisms. International Journal of Systematic Theology 16: 331-50. [CrossRef]

Vatter, Miguel. 2021. Divine Democracy: Political Theology after Carl Schmitt. Oxford: Oxford University Press.

Volf, Miroslav. 1998. "The Trinity Is Our Social Program": The Doctrine of the Trinity and the Shape of Social Engagement. Modern Theology 14: 403-23. [CrossRef]

Volf, Miroslav. 2021. Apophatic Social Trinitarianism: Why I Continue to Espouse a "Kind" of Social Trinitarianism. Political Theology 22: 407-22. [CrossRef]

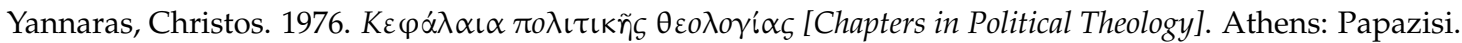

Yannaras, Christos. 1983b. A Note on Political Theology. Translated by Steven Tsichlis. St. Vladimir's Theological Quarterly $27:$ 53-56.

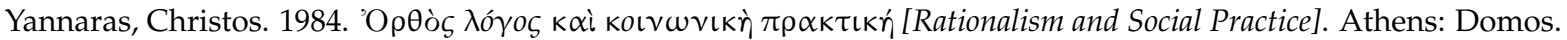

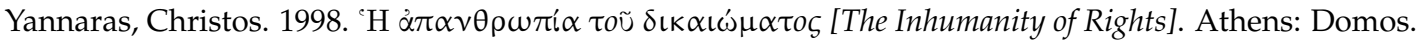

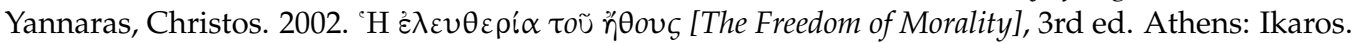

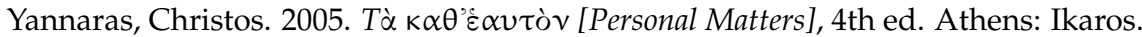

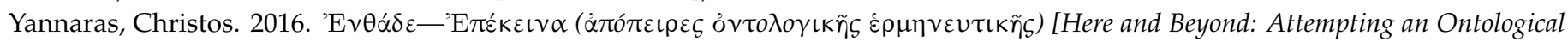
Hermeneutic]. Athens: Ikaros.

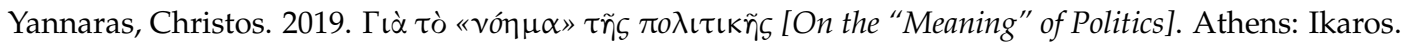

